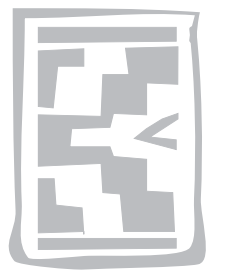

\title{
A study of the pathology and pathogenesis of the myocardial lesions in gousiekte, a plant-induced cardiotoxicosis of ruminants
}

\author{
L. PROZESKY ${ }^{1}$, S.S. BASTIANELLO ${ }^{2}$, N. FOURIE ${ }^{3}$ and R.A. SCHULTZ ${ }^{4}$
}

\begin{abstract}
PROZESKY, L., BASTIANELLO, S.S., FOURIE, N. \& SCHULTZ, R.A. 2005. A study of the pathology and pathogenesis of the myocardial lesions in gousiekte, a plant-induced cardiotoxicosis of ruminants. Onderstepoort Journal of Veterinary Research, 72:219-230

Myocardial lesions were studied in sheep in which gousiekte was induced by experimental dosage of Pachystigma pygmaeum, Fadogia homblei or Pavetta harborii. The single most consistent diagnostic histological feature in 33 animals was hypertrophy of myocardial fibres in the subendocardial region. Fibrosis in the subendocardial region of the apex or left ventricular wall was often scarce or absent in animals with a short latent period, and was not always prominent even in sheep with an intermediate or long latent period. The presence or absence of fibrosis cannot therefore be used to confirm or exclude gousiekte, particularly in cases with shorter latent periods. Light microscopical and ultrastructural lesions in sheep with gousiekte correspond to a large extent to changes reported in humans with dilated cardiomyopathy of unknown cause. It appears that the myocardial lesions in gousiekte represent a final common pathway of cellular damage rather than a manifestation of a specific type of heart disease. The predilection for hypertrophy of myofibres in the subendocardial region is probably related to diminished perfusion that potentiates the primary myocardial dysfunction.
\end{abstract}

Keywords: Cardiotoxicosis, dilated cardiomyopathy, Fadogia homblei, gousiekte, Pachystigma pygmaeum, pathogenesis, pathology, Pavetta harborii, ruminants, South Africa

\section{INTRODUCTION}

Gousiekte is a cardiotoxicosis of ruminants characterized by acute heart failure without the development of premonitory signs 4-8 weeks after the ingestion of certain rubiaceous plants. Grossly, extra-cardiac signs of heart failure are seen in many, but not all, cases. A diagnosis of gousiekte is traditionally confirmed by the presence of appro-

1 Department of Paraclinical Sciences, Faculty of Veterinary Science, University of Pretoria, Private Bag X04, Onderstepoort, 0110 South Africa. E-mail: leon.prozesky@up.ac.za

2 Gribbles VetLab, 33 Flemington Street, Glenside, SA 5065, Australia

3 Intervet, Private Bag X2026, Isando, 1600 South Africa

4 Division of Toxicology. Onderstepoort Veterinary Institute, Private Bag X05, Onderstepoort, 0110 South Africa

Accepted for publication 20 April 2005-Editor priate microscopical lesions in the myocardium, namely loss of myofibres, replacement fibrosis and lymphocytic infiltrates of varying intensity, especially in the subendocardial zone of the apex and left ventricular free wall (Newsholme \& Coetzer 1984; Kellerman, Coetzer \& Naudé 1988).

Smit (1959) noted that some naturally poisoned animals showed more acute changes than those described above, with degeneration of myofibres as the principle lesion. Marked deviations from the "typical" lesions have also been reported in certain experimental cases. Hurter, Naudé, Adelaar, Smit \& Codd (1972) described fairly severe focal degeneration of myocardial fibres, accompanied by congestion, oedema and small haemorrhages. They attributed these more acute lesions to the high dosage of plant material administered to the animals. Furthermore, deaths of animals without 
notable lesions were reported in dosing trials by Adelaar, Terblanche \& Smit (1966) and Anderson \& Naudé (Onderstepoort Veterinary Institute, unpublished data 1959-1962) and were erroneously deemed negative for gousiekte. Since a diagnosis of the disease can be confirmed only by histopathological examination, it is imperative to describe the full spectrum of lesions of gousiekte so that even "atypical" disease can be diagnosed accurately. The need for accurate diagnosis of gousiekte is especially pressing because the toxicity of chemical fractions of the plants can be estimated only by dosing them to ruminants. If the unusual lesions seen occasionally under experimental conditions cannot be identified as caused by gousiekte, the danger exists that toxic fractions could be discarded unwittingly.

There appears to be a close similarity in the pattern of myocardial fibrosis in animals that die of gousiekte and that in humans with dilated cardiomyopathy. The latter is regarded as a syndrome in which a variety of aetiological factors such as viral infections, toxic agents, chronic alcohol abuse and genetic factors have been implicated (Weekes, Wheeler, Yan, Weil, Eschenhagen, Scholtysik \& Dunn 1999). Unverferth (1985) identified fibrosis of increasing severity from epi- to endocardium in patients with dilated cardiomyopathy.

The aim of this study was, firstly, to investigate the effect of duration of latency on the nature of the myocardial histopathological lesions in gousiekte and, secondly, to characterize lesion patterns in animals with short, medium (intermediate) and long latent periods respectively, latent period being defined as the elapsed time between first exposure of the animal to toxic plant material and death of the animal. The need to explain mortality of sheep without the development of "typical" gousiekte lesions was a further factor that prompted the study.

\section{MATERIALS AND METHODS}

\section{Series 1}

Thirty-three sheep of different sexes and ages were dosed separately in unrelated trials with varying amounts of the rubiaceous plant, Pachystigma pygmaeum, Fadogia homblei, Pavetta harborii or an extract of $P$. harborii (Table 1).

The trials from which the data were extracted were carried out over several years and are described in detail by Fourie (1994) and Fourie, Schultz, Prozesky, Kellerman \& Labuschagne (1989). All 33 animals either died or were slaughtered in extremis between
27 and 57 days after the commencement of dosing. At necropsy, samples of various organs and two to three tissue samples from the left free ventricular wall were collected in $10 \%$ buffered formalin. They were routinely processed for histopathological examination and sections were stained with haematoxylin and eosin (HE) and Masson's trichrome stain for collagen (Anon. 1968).

\section{Series 2}

Specimens were collected from the free left ventricular wall from seven of the 33 sheep in Series 1 and from two others (Table 2) for transmission electron microscopy. Cubes $(0.5-1.0 \mathrm{~mm})$ were cut and fixed in $2.5 \%$ glutaraldehyde $(\mathrm{pH} \mathrm{7.2-7.4)}$ for $24 \mathrm{~h}$. Selected blocks were post-fixed in $2 \%$ osmium tetroxide for $1 \mathrm{~h}$, dehydrated in a graded ethanol series (50-100\%), passed through propylene oxide as the intermediate solvent, and embedded in EMBed 812. Thick (1-2 micron) sections were cut for tissue orientation and stained with toluidine blue. Thin sections from selected blocks were stained at room temperature for $20 \mathrm{~min}$ in a saturated aqueous solution of uranyl acetate, rinsed and post-stained for 3 min in Reynold's lead citrate.

\section{RESULTS}

\section{Gross pathology}

Sheep in Series 1 were divided into three groups on the basis of data from field and experimental cases on the length of the latent period. Sheep with a short latent period ( $<35$ days) were placed in Group A, those with an intermediate period (35-41 days) in Group B, and those with a long period (> 41 days) in Group C (Table 3).

Pulmonary oedema was present in $24(73 \%)$ of the sheep, hydropericardium in $20(61 \%)$ and hydrothorax in 12 (36\%) (Fig. 1 and 2). Ascites was evident in three $(9 \%)$ cases and generalised congestion in five (15\%). Seven of the eight cases of ascites and/or generalised congestion occurred in sheep with a long latent period. Other lesions noted were mild and included nephrosis, hepatomegaly, splenomegaly and oedema of the mediastinum, mesenterium, abomasum and the wall of the gall bladder.

In $22(66 \%)$ sheep, one or more of three cardiac lesions, namely dilatation (subjectively evaluated) (Fig. 3), subendocardial fibrosis (pallor) or myocardial mottling, were present. Seventeen sheep (51\%) exhibited dilatation or subendocardial pallor (fibrosis) and only $5(15 \%)$ myocardial mottling. 
L. PROZESKY et al.

TABLE 1 Sheep examined in Series 1 after dosing with different gousiekte plants

\begin{tabular}{|c|c|c|c|c|c|c|c|c|}
\hline Sheep no. & Sexa & $\mathrm{Age}^{\mathrm{b}}$ & $\begin{array}{l}\text { Initial live } \\
\text { mass } \\
(\mathrm{kg})\end{array}$ & $\begin{array}{l}\text { Dried material } \\
\text { dosed }^{c}\end{array}$ & $\begin{array}{l}\text { Dosing } \\
\text { regimen } \\
\text { (g/kgxday) }\end{array}$ & $\begin{array}{l}\text { Total dose } \\
(\mathrm{kg})\end{array}$ & $\begin{array}{l}\text { Last } \\
\text { dosing } \\
\text { (day) }\end{array}$ & $\begin{array}{l}\text { Duration of } \\
\text { experiment } \\
\text { (day) }\end{array}$ \\
\hline $1-4172$ & W & $\mathrm{L}$ & 22 & P. pygmaeum & $13.6 \times 20$ & 6.30 & 26 & 27 \\
\hline $2-6713$ & W & L & 32 & P. harborii ex & $0.57 \times 14$ & 8.00 & 17 & 27 \\
\hline 3-5077 & W & $4 t$ & 29 & P. pygmaeum & $10.3 \times 31$ & 9.30 & 30 & 31 \\
\hline $4-4982$ & W & $\mathrm{L}$ & 31 & P. pygmaeum & $10 \times 23$ & 7.13 & 30 & 31 \\
\hline $5-3874$ & $\mathrm{E}$ & $\mathrm{L}$ & 22 & P. pygmaeum & $10 \times 30$ & 6.60 & 34 & 34 \\
\hline $6-6248$ & $\mathrm{R}$ & $2 \mathrm{t}$ & 38 & F. homblei & $10 \times 22$ & 8.36 & 29 & 34 \\
\hline 7-5231 & W & A & 60 & P. harborii & $10 \times 20$ & 12.00 & 19 & 34 \\
\hline $8-3885$ & $\mathrm{E}$ & $\mathrm{L}$ & 27 & P. pygmaeum & $10 \times 30$ & 8.10 & 34 & 35 \\
\hline $9-3727$ & W & $2 \mathrm{t}$ & 35 & P. pygmaeum & $15 \times 6$ & 9.12 & 34 & 35 \\
\hline $10-5217$ & W & A & 53 & P. harborii & $10 \times 35$ & 18.55 & 34 & 35 \\
\hline $11-3899$ & $E$ & $\mathrm{~L}$ & 25 & P. pygmaeum & $10 \times 30$ & 7.50 & 34 & 36 \\
\hline $12-3890$ & $\mathrm{E}$ & $\mathrm{L}$ & 33 & P. pygmaeum & $10 \times 30$ & 9.90 & 34 & 38 \\
\hline $13-6346$ & $\mathrm{R}$ & L & 36 & F. homblei & $10 \times 22$ & 7.92 & 29 & 40 \\
\hline $14-5051$ & W & $4 t$ & 29 & P. pygmaeum & $10.3 \times 31$ & 9.30 & 30 & 42 \\
\hline $15-3904$ & $\mathrm{E}$ & $\mathrm{L}$ & 27 & P. pygmaeum & $10 \times 30$ & 8.10 & 34 & 42 \\
\hline $16-4977$ & W & $\mathrm{L}$ & 35 & P. pygmaeum & $10 \times 30$ & 10.50 & 39 & 42 \\
\hline $17-6317$ & $\mathrm{E}$ & $4 t$ & 39 & F. homblei & $10 \times 22$ & 8.58 & 29 & 42 \\
\hline $18-4983$ & W & $\mathrm{L}$ & 31 & P. pygmaeum & $10 \times 31$ & 9.61 & 42 & 43 \\
\hline $19-5109$ & $E$ & $4 t$ & 34 & F. homblei & $10 \times 40$ & 13.60 & 40 & 44 \\
\hline $20-5068$ & W & $2 \mathrm{t}$ & 24 & P. pygmaeum & $12.2 \times 25$ & 7.50 & 25 & 45 \\
\hline $21-6375$ & $\mathrm{E}$ & $2 \mathrm{t}$ & 34 & F. homblei & $10 \times 22$ & 7.48 & 29 & 45 \\
\hline $22-6363$ & $\mathrm{E}$ & $4 t$ & 40 & F. homblei & $10 \times 22$ & 8.80 & 29 & 45 \\
\hline $23-4915$ & $\mathrm{R}$ & $\mathrm{L}$ & 41 & P. pygmaeum & $10 \times 19$ & 7.79 & 24 & 45 \\
\hline $24-5256$ & W & A & 59 & P. harborii & $10 \times 20$ & 11.80 & 27 & 50 \\
\hline $25-4984$ & W & $\mathrm{L}$ & 25 & P. pygmaeum & $10 \times 31$ & 7.75 & 42 & 51 \\
\hline $26-4979$ & W & $\mathrm{L}$ & 28 & P. pygmaeum & $10 \times 31$ & 8.68 & 42 & 51 \\
\hline $27-6232$ & W & $4 \mathrm{t}$ & 31 & P. pygmaeum & $10 \times 34$ & 10.54 & 44 & 51 \\
\hline $28-5244$ & W & A & 56 & P. harborii & $10 \times 34$ & 19.04 & 45 & 54 \\
\hline $29-3708$ & $\mathrm{R}$ & $\mathrm{L}$ & 59 & P. harborii & 10 x 32 & 18.88 & 44 & 54 \\
\hline $30-6258$ & $\mathrm{R}$ & $\mathrm{L}$ & 36 & F. homblei & $10 \times 22$ & 7.92 & 29 & 57 \\
\hline $31-6314$ & $\mathrm{E}$ & $2 \mathrm{t}$ & 34 & F. homblei & $10 \times 22$ & 7.48 & 29 & 57 \\
\hline $32-6364$ & $E$ & $4 t$ & 34 & F. homblei & $10 \times 22$ & 7.48 & 29 & 57 \\
\hline $33-6386$ & $\mathrm{E}$ & $4 \mathrm{t}$ & 32 & F. homblei & $10 \times 22$ & 7.04 & 29 & 57 \\
\hline
\end{tabular}

a $\mathrm{R}=\mathrm{Ram}$

$\mathrm{E}=\mathrm{Ewe}$

$\mathrm{W}=$ Wether

b $A=$ Adult

$2 t=2$ tooth

$4 \mathrm{t}=4$ tooth

$\mathrm{L}=\mathrm{Lamb}$

$c$ ex $=$ extract

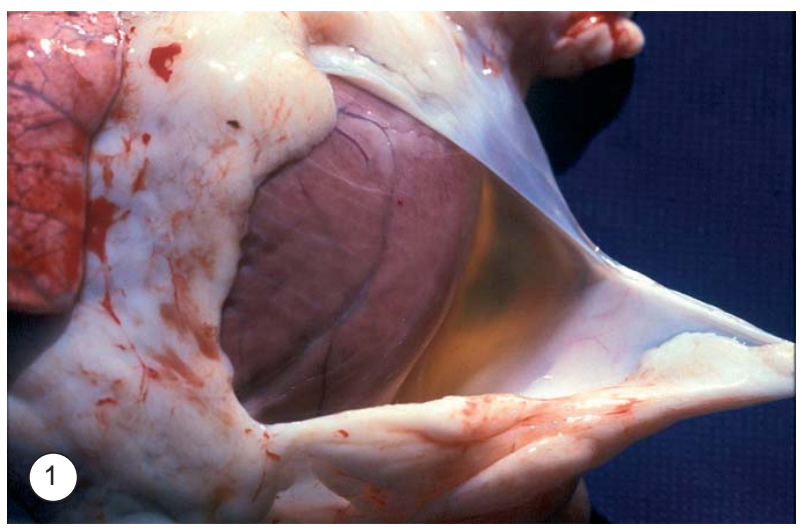

FIG. 1 Hydropericardium in a sheep that died after a long latent period

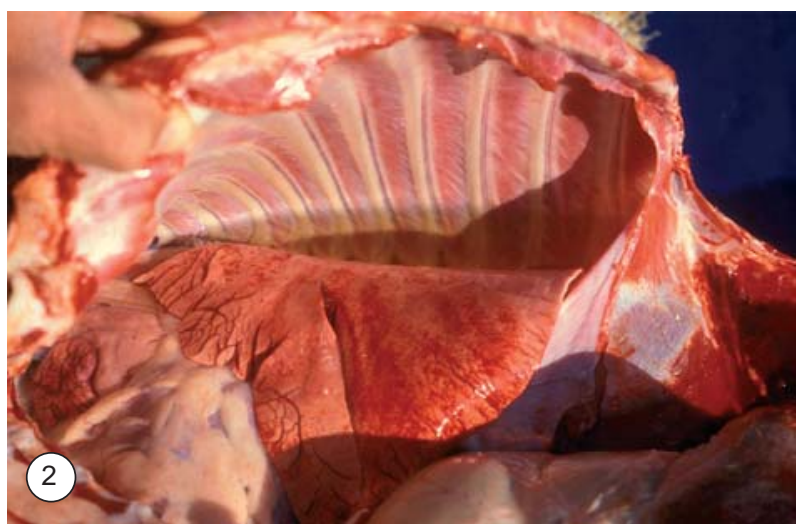

FIG. 2 Note the lung oedema and hydrothorax 
Myocardial lesions in gousiekte, a plant-induced cardiotoxicosis of ruminants

TABLE 2 Sheep examined in Series 2 after dosing with different gousiekte plants

\begin{tabular}{|c|c|c|c|c|c|c|}
\hline Sheep no. & $\begin{array}{l}\text { Initial } \\
\text { live mass } \\
(\mathrm{kg})\end{array}$ & $\begin{array}{l}\text { Dried material } \\
\text { dosed }\end{array}$ & $\begin{array}{l}\text { Period dosed } \\
\text { (days) }\end{array}$ & $\begin{array}{l}\text { Dose } \\
\text { (g/kg } \times \text { day) }\end{array}$ & $\begin{array}{l}\text { Total dose } \\
(\mathrm{kg})\end{array}$ & $\begin{array}{l}\text { Duration of } \\
\text { experiment (days) } \\
\text { and fate }\end{array}$ \\
\hline 1 & 26.5 & P. pygmaeum & 34 & $10 \times 30$ & 7.95 & $\begin{array}{l}36 \\
\text { Killed in extremis }\end{array}$ \\
\hline 2 & 25 & P. pygmaeum & 34 & $10 \times 30$ & 7.50 & $\begin{array}{l}36 \\
\text { Killed in extremis }\end{array}$ \\
\hline 3 & 38 & F. homblei & 30 & $10 \times 22$ & 8.36 & $\begin{array}{l}34 \\
\text { Died }\end{array}$ \\
\hline 4 & 36 & F. homblei & 29 & $10 \times 22$ & 7.92 & $\begin{array}{l}40 \\
\text { Killed in extremis }\end{array}$ \\
\hline 5 & 34 & F. homblei & 29 & $10 \times 22$ & 7.48 & $\begin{array}{l}57 \\
\text { Died }\end{array}$ \\
\hline 6 & 32 & F. homblei & 29 & $10 \times 22$ & 7.04 & $\begin{array}{l}57 \\
\text { Died }\end{array}$ \\
\hline 7 & 34 & F. homblei & 29 & $10 \times 22$ & 7.48 & $\begin{array}{l}57 \\
\text { Died }\end{array}$ \\
\hline 8 & 36 & F. homblei & 30 & $10 \times 22$ & 7.92 & $\begin{array}{l}57 \\
\text { Killed in extremis }\end{array}$ \\
\hline 9 & 27 & P. pygmaeum & $\begin{array}{l}24 \\
10 \\
8\end{array}$ & $\begin{array}{l}10 \times 19 \\
10 \times 7 \\
8 \times 6\end{array}$ & 8.32 & $\begin{array}{l}72 \\
\text { Killed in extremis }\end{array}$ \\
\hline
\end{tabular}

TABLE 3 Macroscopic pathological features in 33 sheep in Series 1

\begin{tabular}{|c|c|c|c|c|c|c|}
\hline \multirow{2}{*}{\multicolumn{2}{|c|}{ Macroscopic pathological feature }} & \multicolumn{5}{|c|}{ Number of animals affected } \\
\hline & & $\begin{array}{l}\text { Group } A^{a} \\
(n=7)\end{array}$ & $\begin{array}{l}\text { Group } \mathrm{B}^{\mathrm{b}} \\
(n=6)\end{array}$ & $\begin{array}{l}\text { Group } C^{c} \\
(n=20)\end{array}$ & $\begin{array}{l}\text { Total } \\
(n=33)\end{array}$ & $\begin{array}{l}\text { Percentage } \\
\text { per feature }\end{array}$ \\
\hline \multicolumn{2}{|c|}{ Pulmonary oedema } & 4 & 5 & 15 & 24 & 73 \\
\hline \multicolumn{2}{|c|}{ Hydropericardium } & 5 & 5 & 10 & 20 & 61 \\
\hline \multicolumn{2}{|c|}{ Hydrothorax } & 2 & 2 & 8 & 12 & 36 \\
\hline \multicolumn{2}{|c|}{ Generalized congestion } & 1 & 0 & 4 & 5 & 15 \\
\hline \multicolumn{2}{|c|}{ Ascites } & 0 & 0 & 3 & 3 & 9 \\
\hline Heart & $\begin{array}{l}\text { Cardiac dilatation } \\
\text { Left ventricular subendo- } \\
\text { cardial pallor (fibrosis) } \\
\text { Myocardial mottling }\end{array}$ & $\begin{array}{l}1 \\
0 \\
1\end{array}$ & $\begin{array}{l}1 \\
0 \\
0\end{array}$ & $\begin{array}{l}7 \\
8 \\
4\end{array}$ & $\begin{array}{l}9 \\
8 \\
5\end{array}$ & $\begin{array}{l}27 \\
24 \\
15\end{array}$ \\
\hline
\end{tabular}

a Short latent period $<35$ days

b Intermediate latent period 35-41 days

c Long latent period $>41$ days

\section{Histopathology}

The pertinent histopathological features in the left ventricle of sheep dosed with gousiekte plants are tabulated in Table 4. The lesions were located primarily in the subendocardial zone, the four most characteristic features being hypertrophy or atrophy of fibres, focal necrosis and foci of replacement fibro- 

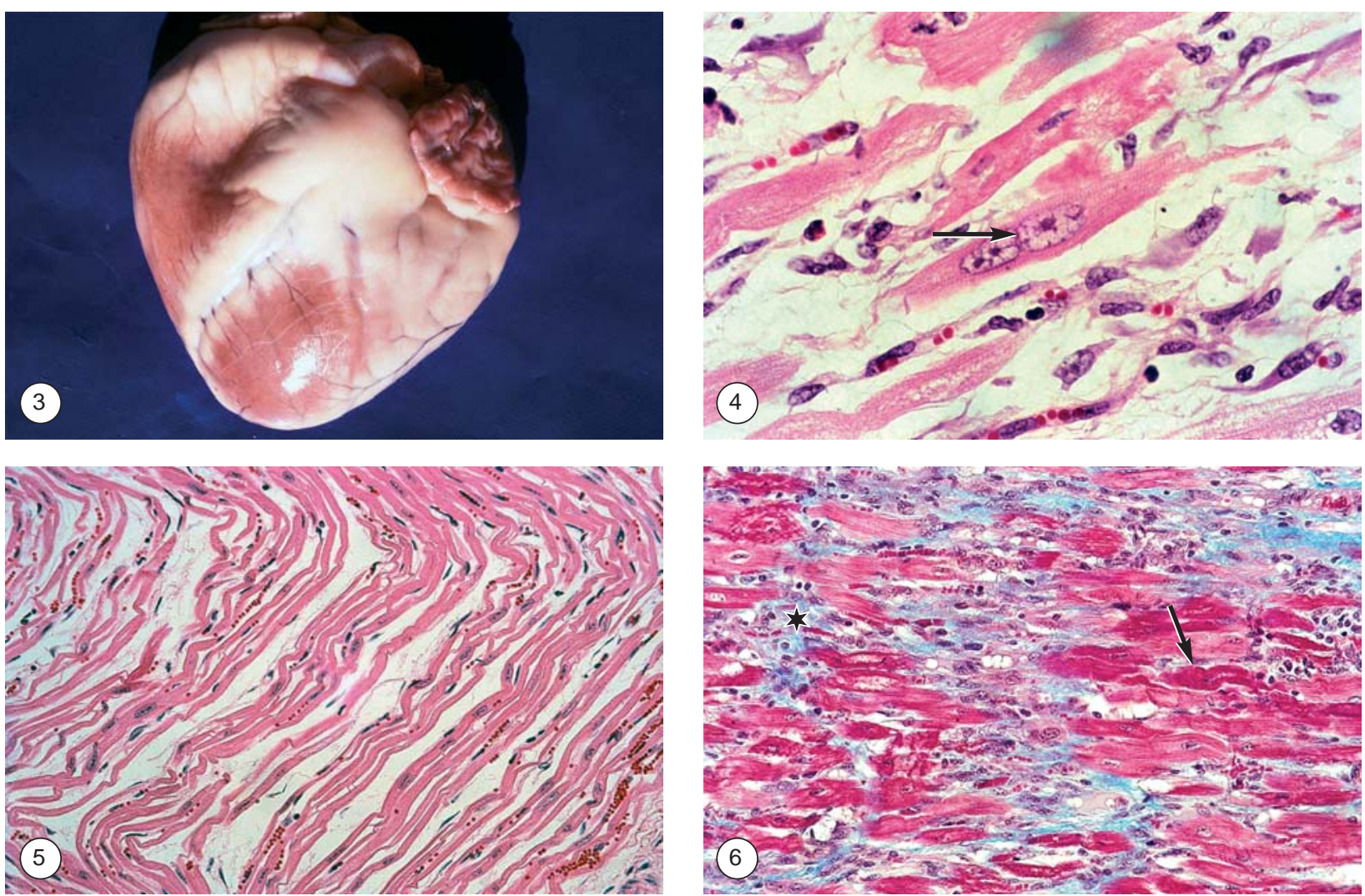

FIG. 3 Enlargement of the heart due to dilation of both ventricles

FIG. 4 Fibre hypertrophy with nuclear hyperplasia (arrow). HE, X 200

FIG. 5 Diffuse atrophy of fibres throughout the myocardium in a sheep with a short latent period. HE, X 100

FIG. 6 Multifocal necrosis (arrow) with replacement fibrosis (star). Masson's trichrome X100

sis (Fig. 4-6). Amongst the other changes noted were foci of round cell infiltration (Fig. 7); focal to diffuse endocardial thickening; pallor and vacuolation of the Purkinje fibres; and myocardial arterial or arteriolar lesions, characterized by medial oedema and hypertrophy accompanied by perivascular accumulation of unidentified cells.

Focal to diffuse areas of hypertrophy in the inner third of the myocardium were recorded in all the sheep. Hypertrophy was mainly mild in nature and multifocal in distribution in those with short latent periods ( $<5$ weeks) and diffuse, moderate or moderately severe in those with intermediate (5-6 weeks) or long latent periods ( $>6$ weeks).

Foci of replacement fibrosis were present in 30 $(91 \%)$ of the sheep. Sheep with short latent periods generally had small, indistinct, scattered foci of fibrosis. In 4 sheep with long latent periods, the fibrosis was extensive and in 15 animals varied from moderate to severe. In sheep with intermediate latent periods, the extent of fibrosis was variable.
Focal areas of coagulative necrosis were evident in $26(79 \%)$ sheep. Vacuolated fibres with perinuclear myocytolysis were often evident closely associated with coagulated fibres. In sheep with short latent periods, the foci were usually small and distributed throughout the left ventricular wall. In sheep with longer latent periods, the foci were scattered in the mid- and subepicardial zones or occurred in close proximity to the fibrotic areas in the subendocardial zone. In sheep with intermediate latent periods necrotic foci were numerous.

Atrophy of myocardial fibres was present in 19 (58\%) sheep and was generally focal, involving individual or small groups of fibres. In four sheep with long latent periods, extensive tracts of atrophic fibres were present in the subendocardial zone. In two sheep having short latent periods, atrophy was evident diffusely throughout the myocardium.

Foci of round cell infiltration were recorded in all the sheep. The foci were generally small, contained few cells and were composed mainly of small lympho- 
Myocardial lesions in gousiekte, a plant-induced cardiotoxicosis of ruminants

TABLE 4 Histopathological lesions in the hearts of 33 sheep in Series 1

\begin{tabular}{|c|c|c|c|c|c|c|c|}
\hline \multicolumn{3}{|c|}{ Histopathological features } & \multicolumn{3}{|c|}{ Group of animals } & \multirow{2}{*}{ Total } & \multirow{2}{*}{$\begin{array}{l}\text { Percentage } \\
\text { per feature }\end{array}$} \\
\hline \multicolumn{2}{|l|}{ Features } & $\begin{array}{l}\text { Distribution } \\
n=7\end{array}$ & $\begin{array}{l}\mathrm{A}^{\mathrm{a}} \\
n=6\end{array}$ & $\begin{array}{l}\mathrm{B}^{\mathrm{b}} \\
n=20\end{array}$ & $\begin{array}{l}C^{c} \\
n=33\end{array}$ & & \\
\hline \multicolumn{2}{|c|}{ Myofibre nuclear hypertrophy ${ }^{d}$} & Diffuse & 7 & 6 & 20 & 33 & 100 \\
\hline \multicolumn{2}{|c|}{$\begin{array}{l}\text { Myofibre hypertrophy in } \\
\text { subendocardial myocardiume }\end{array}$} & $\begin{array}{l}\text { Focal } \\
\text { Diffuse }\end{array}$ & $\begin{array}{l}5 \\
2\end{array}$ & $\begin{array}{l}1 \\
5\end{array}$ & $\begin{array}{r}0 \\
20\end{array}$ & 33 & 100 \\
\hline \multicolumn{2}{|c|}{$\begin{array}{l}\text { Focal disorganization of myofibres in } \\
\text { subendocardial myocardium }{ }^{f}\end{array}$} & - & 7 & 5 & 19 & 31 & 94 \\
\hline \multicolumn{2}{|c|}{ Replacement fibrosis } & $\begin{array}{l}\text { Scattered foci } \\
\text { Extensive tracts }\end{array}$ & $\begin{array}{l}6 \\
0\end{array}$ & $\begin{array}{l}5 \\
0\end{array}$ & $\begin{array}{r}15 \\
4\end{array}$ & 30 & 91 \\
\hline \multicolumn{2}{|c|}{$\begin{array}{l}\text { Focal areas of coagulative/ necrosis/ } \\
\text { myocytolysis of fibres }\end{array}$} & Scattered foci & 6 & 6 & 14 & 26 & 79 \\
\hline \multicolumn{2}{|c|}{ Myofibre atrophy } & $\begin{array}{l}\text { Focal } \\
\text { Diffuse }\end{array}$ & $\begin{array}{l}4 \\
2\end{array}$ & $\begin{array}{l}3 \\
0\end{array}$ & $\begin{array}{r}10 \\
0\end{array}$ & 19 & 58 \\
\hline \multicolumn{2}{|c|}{ Foci of round cell infiltration } & Scattered foci & 7 & 7 & 20 & 33 & 100 \\
\hline \multicolumn{2}{|c|}{ Endocardial thickening } & $\begin{array}{l}\text { Focal } \\
\text { Diffuse }\end{array}$ & $\begin{array}{l}2 \\
4\end{array}$ & $\begin{array}{l}1 \\
2\end{array}$ & $\begin{array}{r}0 \\
18\end{array}$ & 27 & 82 \\
\hline \multicolumn{2}{|c|}{$\begin{array}{l}\text { Purkinje fibre pallor and/or } \\
\text { vacuolation }\end{array}$} & - & 7 & 4 & 15 & 26 & 79 \\
\hline $\begin{array}{l}\text { Myocardial } \\
\text { vessels }\end{array}$ & $\begin{array}{l}\text { Medial oedema/ } \\
\text { perivascular cellular } \\
\text { infiltration } \\
\text { Medial hypertrophy }\end{array}$ & - & 3 & 4 & 13 & 20 & 61 \\
\hline
\end{tabular}

Short latent period $<35$ days

Intermediate latent period 35-41 days

Long latent period $>41$ days

$d, e, f \quad$ All represent features of myocardial hypertrophy

cytes, except for three sheep with long latent periods, where the foci were prominent and contained moderate to large numbers of cells. The foci were widely distributed throughout the interstitium, especially perivascularly, in all cases. In the sheep with the long latent periods, the majority of foci were found closely associated with the areas of fibrosis and necrosis in the subendocardial zone.

Focal to diffuse, mild to moderate thickening of the endocardium was evident in 27 (82\%) cases. In sheep with short or intermediate latent periods, it was usually mild and either focal or diffuse in nature. In contrast, in sheep with a long latent period, all but two exhibited diffuse, moderate to severe thickening of the endocardium.

In 26 (79\%) sheep the Purkinje fibres were pale staining, and many contained single or multiple, indistinct to prominent vacuoles.
Examination of the myocardial arteries and arterioles disclosed vacuolation of the tunica media and a perivascular accumulation of cells of an indeterminate origin in $20(61 \%)$ cases. Hypertrophy of the tunica media of these vessels was evident in 23 (70\%) sheep. The hypertrophy was usually mild and in only four cases was it prominent.

\section{Transmission electron microscopy}

A common finding in degenerative myocardial cells was myofibrillar loss that varied significantly in degree from cell to cell within the same animal. Single or multiple sarcomeres within a myofibril were affected. Mild myofibril loss was characterized by widening of the perinuclear myofibrillar free zone, whereas more advanced loss resulted in large myofibril-free areas of cytoplasm in the central part of the myofibre, with a few intact peripheral myofibrils below the sarco- 

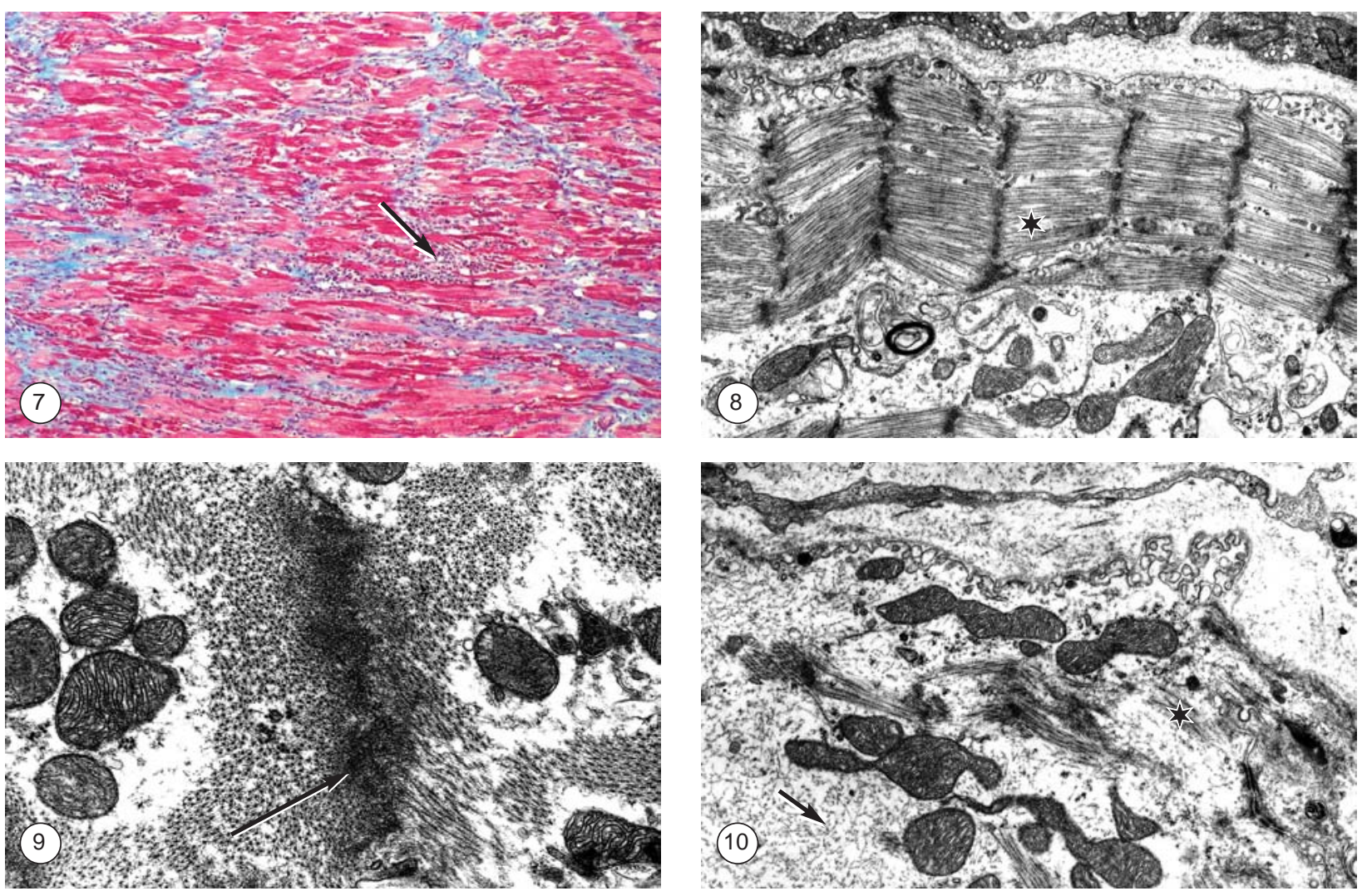

FIG. 7 Multifocal small foci of predominantly lymphocytic infiltration (arrow) were present in all the sheep. Masson's trichrome X100

FIG. 8 Degenerative fibrils had a frayed appearance (star)

FIG. 9 Note disintegrated myofilaments in cross section (arrow)

FIG. 10 Disintegrated myofilaments (arrow) were often intermingled with cellular organelles, e.g. mitochondria. Intercalated disc (star)

lemma. Degenerative fibrils had a frayed appearance with a preferential loss of thin (actin) filaments (Fig. 8 and 9). A common finding in degenerative cells was the presence of fine tangled (interwoven) fibrillar masses representing disintegrated myofilaments, often intermingled with cellular organelles (Fig. 10 and 11). Myocardial cells with advanced myofibrillar loss were atrophic (Fig. 12), with a decreased cell diameter, whereas cells with a moderate degree of myofibrillar loss maintained a normal cell diameter as a result of the proliferation of other cytoplasmic components, particularly mitochondria.

Scattered $Z$ bands were irregularly thickened and often fragmented, with streaking of the affected $Z$ band material into the surrounding myofibrillar tissue and cytoplasm (Fig. 12). Cells with more advanced degenerative changes were characterized by the selective proliferation of certain organelles, namely mitochondria (Fig. 13 and 14) and sarcoplasmic reticulum (Fig. 15), and the deposition of material in areas previously occupied by myofibrils. This material included glycogen, homogenous residual bodies (suspected lipid), electron dense bodies, myelin figures of unknown origin, or a fine fibrillar matrix (lysed myofilaments).

Mitochondria varied considerably in size and shape and showed various alterations including pyknosis, the formation of concentric cristae and an increase in the size, number and density of dense granules. Rupture of swollen cristae was frequently noted and varied in extent from lysis of a few cristae to complete loss of cristae, resulting in an empty external mitochondrial membrane or the accumulation of moderately electron dense material replacing the internal structure of the mitochondria. There were indications that damage to mitochondria on occasion resulted in the formation of concentric layers of electron dense membrane material (myelin figures).

Medium electron dense material, which was enclosed by a single or double membrane or was intermingled with dissociated fibrils and cellular organelles, was occasionally noted in degenerative cells. This was considered a form of intracellular oedema. 

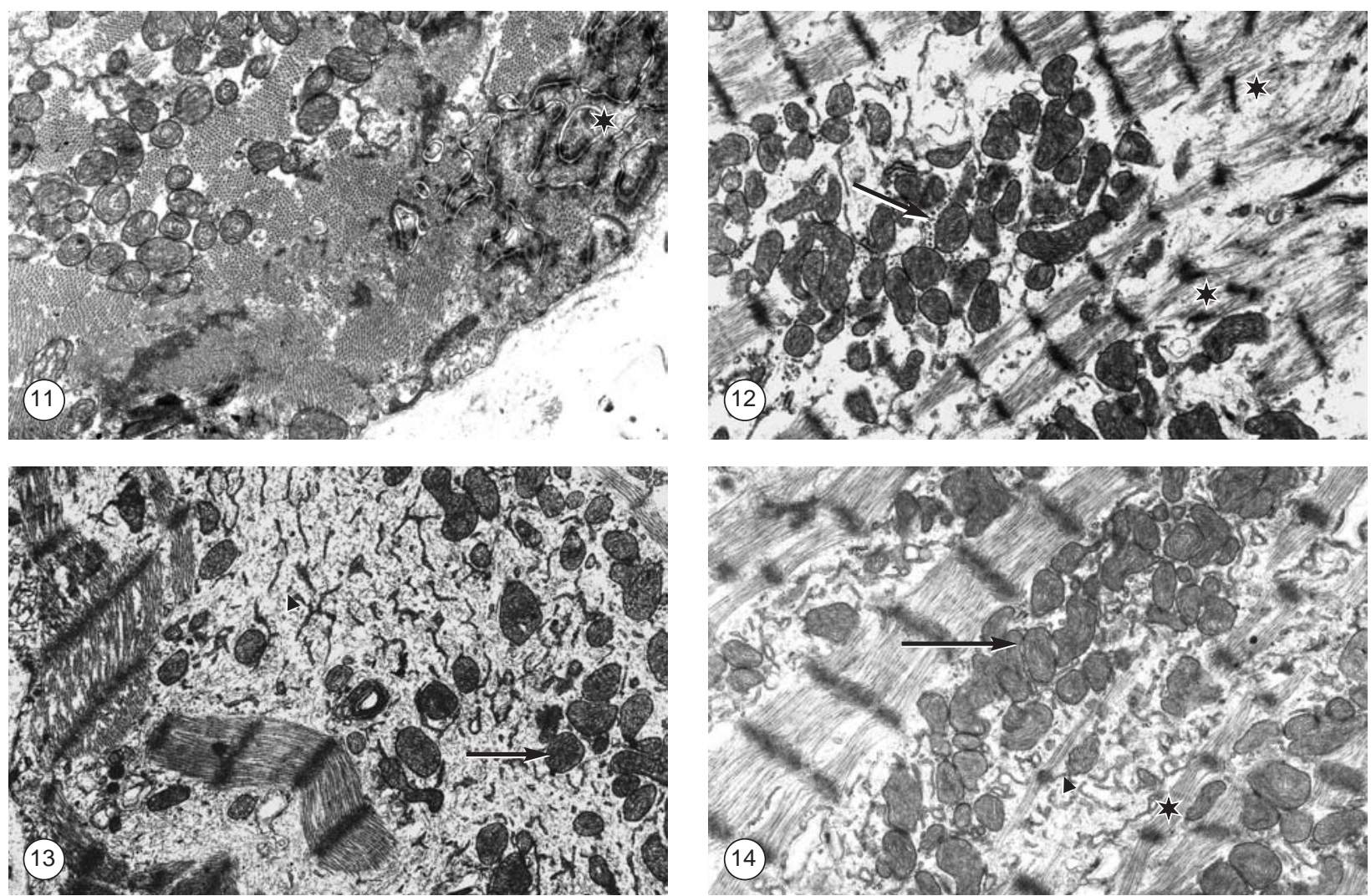

FIG. 11 Cross section of myofibre. Note complex folding of intercalated disc (star)

FIG. 12 Myocardial cells with advanced myofibrillar loss were atrophic. Note streaking of Z-band material (star) and mitochondria proliferation (arrow)

FIG. 13 Disintegrated myofibre. Note mitochondria (arrow) and sarcoplasmic reticulum proliferation (arrow head)

FIG. 14 Myofibre with advanced myofibrillar loss due to myofilament disintegration (star). Note mitochondria proliferation (arrow) and sarcoplasmic reticulum proliferation (arrow head)

Changes in the sarcoplasmic reticulum included dilatation and proliferation. The latter was particularly notable in areas of myofibrillar loss and was often seen in conjunction with mitochondrial proliferation and the accumulation of glycogen deposits. Occasional degenerative cells were noted in association with dilated transverse tubules.

The most striking intercalated disc abnormality noted was a significant increase in length resulting from the development of complex folds. The folded discs were associated with cells that exhibited a wide spectrum of degenerative changes, particularly disintegration of myofilaments ranging from mild to severe. Many of the affected discs exhibited multiple small areas of separation of the two opposing unit membranes (Fig. 13). Complete separation between cells at the level of the intercalated disc was also noted.

The intercellular space between degenerative cells was often distended and contained numerous membrane bound empty spaces that varied in size and shape, ranging from circular to oval or pleomorphic. Some of these structures were attached to the sarcolemma and appeared to represent excessive folding of it (Fig. 10). Similar structures were also present in the subjacent sarcolemmal sarcoplasma.

\section{DISCUSSION}

Certain gross lesions are suggestive of gousiekte as the cause of death. These include signs of left-sided heart failure, such as pulmonary oedema, hydropericardium and hydrothorax, and specific cardiac lesions, particularly cardiac dilatation and subendocardial fibrosis.

The presence of pulmonary oedema, hydropericardium and/or hydrothorax in most of the sheep in this study suggests that gousiekte causes left-sided heart failure. Features suggestive of congestive (biventricular) heart failure, such as generalized congestion and/or ascites, were less common. Seven 
of the eight sheep with either ascites or generalized congestion had long latent periods, and the myocardial lesions were widespread, stretching from the apex and left free ventricular wall to the septum and right free ventricular wall. This suggests that congestive heart failure only occurs in cases where the pathological process extends beyond the initial predilection site in the left ventricle. Cardiac dilatation, subendocardial fibrosis or myocardial mottling were evident in two thirds of the sheep examined in this study.

Of the various histopathological lesions recorded, the single most consistent diagnostic feature of gousiekte recorded in this series was hypertrophy of myocardial fibres in the subendocardial region of the left ventricular wall. In cases with a short latent period ( $<5$ weeks), the diagnosis was based on the presence of mild to moderately hypertrophic fibres in the subendocardial myocardium, with small, scattered foci of necrosis and, occasionally, focal areas of fibrosis. A few of the cases with a short latent period exhibited diffuse myocardial atrophy and focal hypertrophy in the absence of necrosis or fibrosis. Cases with a longer latent period ( $>5$ weeks) were more typical of gousiekte and were characterized by diffuse, moderate to severe, subendocardial myocardial fibre hypertrophy, coalescent focal to extensive fibrosis, and multifocal necrosis. In rare instances, fibrosis was absent even in cases with intermediate or long latent periods.

In the past, histopathological confirmation of gousiekte has been based on the presence of moderate to severe coalescent or extensive fibrosis in the subendocardial myocardium of the apex or free wall of the left ventricle (Kellerman et al. 1988). However, in six out of seven sheep with short latent periods in this study, fibrosis was lacking or not prominent, and even in a few sheep with an intermediate or long latent period, fibrosis was absent. The presence or absence of fibrosis on its own cannot therefore be used as a single diagnostic criterion for the confirmation or exclusion of gousiekte, particularly in cases with shorter latent periods.

Focal areas of necrosis were seen in the majority of cases of gousiekte, regardless of whether the latent period was short, intermediate or long. This feature, together with the presence of hypertrophy as discussed above, can be regarded as a significant microscopic lesion for the histopathological diagnosis of gousiekte, especially in cases where fibrosis is minimal and focal in nature or completely absent.

Myocardial fibre atrophy, although mostly focal in nature and present in only $58 \%$ of cases, should be regarded as one of the diagnostic features of gousiekte. It was especially significant in a few cases with a short latent period, where it occurred diffusely in the myocardium in the absence of multifocal fibrosis or prominent myofibre hypertrophy. In the majority of cases, however, myocardial fibre atrophy was usually focal in nature and involved only individual or small groups of fibres. Occasionally diffuse atrophy can be the most striking histological feature in field cases of gousiekte (Prozesky, Fourie, Neser \& Nel 1988).

Round cell infiltrates in the myocardium have in the past been regarded as a feature of gousiekte (Smit 1959). Although present in all cases with long latent periods in this study, these infiltrations were only prominent in three sheep. Round cells occurred in small indistinct foci consisting of a few cells in the myocardial interstitium, especially around blood vessels or in association with foci of fibrosis or necrosis. The small number of cells and the association thereof with myocardial necrosis or fibrosis imply that they accumulate in response to necrosis of myofibres. Foci of round cell infiltrates may be present in a variety of cardiac conditions and should not be regarded as a specific diagnostic feature of gousiekte.

Other features that may be present, such as endocardial thickening, pallor and vacuolation of the Purkinje fibres, and arterial lesions, which were seen in cases with longer latent periods, were all regarded as secondary.

The most striking ultrastructural degenerative lesions noted in this study included loss of myofibrils, involving particularly thin filaments; deposition of glycogen and residual bodies and selective proliferation of organelles, such as mitochondria and sarcoplasmic reticulum, in areas previously occupied by myofibrils; variation in size and shape of mitochondria with increase in size, number and density of dense granules, and swelling and rupture of cristae; increase in length of the intercalated discs and development of complex folding; excessive folding of the sarcolemma; and irregular thickening and fragmentation of $Z$ bands. Advanced myocardial degeneration was characterized by complete loss of myofibrils with loss of intercellular connections.

To a large extent the light microscopical and ultrastructural lesions described in sheep with gousiekte in this study and a previous report (Schutte, Els, Booyens \& Pienaar 1984) correspond with changes reported in humans with dilated cardiomyopathy of unknown cause (Unverferth 1985). Unverferth (1985) identified fibrosis of increasing severity extending 
from the epi- to the endocardium in patients with dilated cardiomyopathy. In his study fibrosis was more prominent in the left side of the interventricular septum compared to the right. The fibrosis in the subendocardium of the left ventricular free wall was identical to that in the subendocardium on the left side of the interventricular septum, whereas the right ventricular free wall did not demonstrate a gradation in the degree of fibrosis across the wall . A predilection for subendocardial fibrosis may be attributed to the following causes: cellular hypertrophy, aetiological factors, wall stress and an abnormal oxygen supply-to-demand ratio (Unverferth 1985).

The active principle contained by plants inducing gousiekte has been isolated (Fourie 1994; Fourie, Erasmus, Schultz \& Prozesky 1995) and identified as pavetamine (Vleggaar, University of Pretoria, unpublished data 1997). Pavetamine was found to be an inhibiter of myocardial protein synthesis in rats (Schultz, Fourie, Basson, Labuschagne \& Prozesky 2001). The effect of pavetamine on the heart was sustained for at least $48 \mathrm{~h}$, in contrast to the other organs that were either unaffected or recovered rapidly (Schultz et al. 2001).

The term protein turnover is used to describe the continuous synthesis and degradation of muscle protein in the body, including that of myocardium (Swick \& Song 1974; Earl, Laurent, Everett, Bonnin \& Sparrow 1978). In the rat, dog, fowl and mouse it was found that the average protein turnover rate of cardiac muscle was more rapid and that of skeletal muscle slower (Earl et al. 1978). In the rat a ten-fold difference in turnover rate between the ventricles and tensor fasciae latae was found using ${ }^{3} \mathrm{H}$-leucine. Swick \& Song (1974) reported a six-fold difference in turnover rate between myosin from cardiac and skeletal muscle in the rat. Schultz et al. (2001) postulated that while the body is breaking down myocardial protein in its ongoing turnover, pavetamine in experimental rats inhibits the formation of new myocardial protein. Depending on the half-life of the affected cardiac protein, a point will be reached where breakdown of myocardial contractile protein exceeds synthesis, to the extent that heart failure will occur. In bovine hereditary dilated cardiomyopathy a number of proteins are significantly reduced (Weekes et al. 1999). Many of these proteins are found exclusively in the mitochondria, suggesting that in congestive heart failure the myocardium is unable to provide sufficient energy to cope with the increased mechanical stresses.

Dilated cardiomyopathy in humans and animals is characterized by impaired systolic function with reduced ejection fraction and increased end-systolic blood pressure, as the heart adapts to maintain a normal stroke volume (Dec \& Fuster 1994; Weekes et al. 1999). An increase in the cardiac pulmonary flow index (CPFI) (Van der Walt \& Van Rooyen 1977; Fourie et al. 1989) and an increase in the serum aspartate transaminase (AST) (Fourie et al. 1989; Fourie 1994) are reliable clinical and physio-pathological indicators in sheep of cardiac damage in gousiekte. An increase in the CPFI is attributed to a decrease in both stroke volume and pumping efficiency of the left ventricle relative to the right ventricle, resulting in an increase in the ventricular filling pressure and pulmonary blood volume (Pretorius, Terblanche, Van der Walt \& Van Ryssen 1973; Van der Walt \& Van Rooyen 1977; Van Rooyen, Van der Walt, Joubert \& Lotter 1984). Tachycardia and an increase in the CPFI are commonplace in animals with gousiekte during the later stages of the disease (Van der Walt \& Van Rooyen 1977; Van der Walt, Van Rooyen, Cilliers, Van Ryssen \& Van Aarde 1981), i.e. after 35 days (Fourie et al. 1989). Both these factors interfere with adequate myocardial perfusion. This will further interfere with myocardial perfusion, most notably subendocardial tissue, because of an increased intraventricular pressure that is readily transmitted to principally subendocardial coronary arteries (Unverferth 1985).

Transmural distribution of coronary blood flow in the wall of the heart has been studied by various workers (Rudolph \& Heyman 1967). In dogs, the subendocardial tissue has $20 \%$ greater oxygen consumption per unit weight than subepicardial tissue (Weiss, Neubauer, Lipp \& Sinha 1978). There is overwhelming evidence in humans that subendocardial myofibres demonstrate greater ischaemic damage than subepicardial myofibres (Unverferth 1985). Blood flow to the subendocardium normally occurs in diastole, whereas subepicardial flow is maintained in systole and diastole (Rouleau, Boerboom \& Surjadhana 1979). Tachycardia thus reduces diastolic and myocardial perfusion, particularly subendocardial perfusion, and increases oxygen demand (Unverferth 1985). Furthermore, any substantial increase in oxygen demand is met by an increase in coronary blood flow by alterations in coronary vascular resistance. Dilated cardiomyopathy is characterized by a low cardiac output and a low coronary blood flow (Weiss, Ellis, Sciacca, Johnson, Schmidt \& Cannon 1976) and can therefore not meet this demand. From a pathophysiological viewpoint, sheep with gousiekte with a long latent period demonstrate several characteristics that increase the risk of myocardial ischaemia of, in particular, the subendocardial tissue. 
Considering the available information, the following pathogenesis of the myocardial lesions in animals with gousiekte is postulated. Following exposure to gousiekte plants, pavetamine inhibits the formation of new myocardial protein. A point is reached where breakdown of myocardial contractile protein exceeds synthesis to the extent that contractibility of myofibres is affected and heart failure occurs. The majority of animals die without clinical signs of congestive heart failure. Congestive heart failure can, however, occur in animals with a long latent period, and in these animals various degrees of dilated cardiomyopathy and concomitant, primarily subendocardial, fibrosis of the left free ventricular wall and the left side of the interventricular septum is evident. It is hypothesised that the pattern of subendocardial fibrosis is the result of a self-perpetuating cycle resulting from diminished myocardial perfusion, most notably of the subendocardial tissue. Inadequate perfusion may therefore potentiate the primary myocardial dysfunction.

The heart has a limited range of responses to injury, and the response will vary according to the nature, duration and severity of the insult (Newsholme 1982; Kumar, Cotran \& Robbins 2003). The most common myofibre changes seen in animals with gousiekte include varying degrees of hypertrophy, atrophy, necrosis and fibrosis. The myocardial changes in animals with gousiekte therefore appear to represent a final common pathway of cellular damage rather than a manifestation of a specific type of heart disease. There is no evidence that pavetamine selectively affects certain myocardial fibres, and the predilection for hypertrophy of myofibres in the subendocardial region is probably related to the diminished perfusion that potentiates the primary myocardial dysfunction in this region.

\section{REFERENCES}

ADELAAR, T.F., TERBLANCHE, M. \& SMIT, J.D. 1966. A report on negative experiments with ferric chloride as a prophylactic agent against gousiekte. Journal of the South African Veterinary Medical Association, 37:199-201.

ANON. 1968. Manual of histological staining methods, $3^{\text {rd }}$ ed. Armed Forces Institute of Pathology, Washington DC, New York: Mc Graw-Hill.

DEC, G.W. \& FUSTER, V. 1994. Idiopathic dilated cardiomyopathy. New England Journal of Medicine, 331:1564-1575.

EARL, C.A., LAURENT, G.J., EVERETT, A.W., BONNIN, C.M. \& SPARROW, M.P. 1978. Turnover rates of muscle protein in cardiac and skeletal muscles of dog, fowl, rat and mouse. Australian Journal of Experimental Biology and Medical Science. 56:265-277.

FOURIE, N. 1994. Isolation of the cardiotoxin from gousiekteinducing plants and investigation of the pathogenesis and diagnosis of the disease. Ph.D. thesis, University of Pretoria.
FOURIE. N., ERASMUS, G.L., SCHULTZ, R.A. \& PROZESKY, L. 1995. Isolation of the toxin responsible for gousiekte, a plant induced cardiomyopathy of ruminants in southern Africa. Onderstepoort Journal of Veterinary Research, 62: 77-87

FOURIE, N., SCHULTZ, R. ANITRA, PROZESKY, L., KELLERMAN, T.S. \& LABUSCHAGNE LEONIE. 1989. Clinical pathological changes in gousiekte, a plant-induced cardiotoxicosis of ruminants. Onderstepoort Journal of Veterinary Research, 56:73-80.

HURTER, L.R., NAUDE, T.W., ADELAAR, T.F., SMIT, J.D. \& CODD, L.E. 1972. Ingestion of the plant Fadogia monticola Robyns as an additional cause of gousiekte in ruminants. Onderstepoort Journal of Veterinary Research, 39:71-82.

KELLERMAN, T.S., COETZER, J.A.W. \& NAUDÉ, T.W. 1988. Gousiekte, in Plant poisonings and mycotoxicoses of livestock in southern Africa. Cape Town: Oxford University Press.

KUMAR, V., COTRAN, R. \& ROBBINS, S.L. 2003. Robbins basic pathology, 7th ed. Philadelphia, London, Toronto, Montreal, Sydney \& Tokyo: W.B. Saunders Company.

NEWSHOLME, S.J. 1982. Reaction patterns in myocardium in response to injury. Journal of the South African Veterinary Association, 53:52-59.

NEWSHOLME, S.J. \& COETZER, J.A.W. 1984. Myocardial pathology of domestic ruminants in southern Africa. Journal of the South African Veterinary Association, 55:89-96.

PRETORIUS, P.J., TERBLANCHE, M., VAN DER WALT, J.D. \& VAN RYSSEN, J.C.J. 1973. Cardiac failure in ruminants caused by gousiekte, in Cardiomyopathies. Vol. 2, edited by E. Bajusz \& G. Rona. Baltimore: University Park Press.

PROZESKY, L., FOURIE, N., NESER, J.A. \& NEL, P.W. 1988. A field outbreak in Île-de-France sheep of a cardiotoxicosis caused by the plant Pachystigma pygmaeum (Schltr) Robyns (Rubiaceae). Onderstepoort Journal of Veterinary Research, 55:193-196.

ROULEAU, J., BOERBOOM, L.E. \& SURJADHANA, A. 1979. The role of autoregulation of tissue diastolic pressure in the transmural distribution of left ventricular blood flow in anaesthetized dogs. Circulation Research, 45:804 - 815.

RUDOLF, A.M. \& HEYMAN, M.A. 1967. The circulation of the fetus in utero: Methods for studying distribution of blood flow. Circulation Research, 21:163-184.

SCHULTZ, R.A., FOURIE, N., BASSON, K.M., LABUSCHAGNE, L. \& PROZESKY, L. 2001. Effect of pavetamine on protein synthesis in rat tissue. Onderstepoort Journal of Veterinary Research, 68:325-330.

SCHUTTE, P.J., ELS, H.J., BOOYENS, J. \& PIENAAR, J.G. 1984. Ultrastructure of myocardial cells in sheep with congestive heart failure induced by Pachystigma pygmaeum. South African Journal of Science, 80:378-380.

SMIT, J.D. 1959. Die histopatologiese diagnose van gousiekte. Journal of the South African Veterinary Medical Association, 30:447-450.

SWICK, R.W. \& SONG, H. 1974. Turnover of various muscle proteins. Journal of Animal Science, 38:1150-1157.

UNVERFERTH, D. 1985. Dilated cardiomyopathy. Mount Kisco, New York: Futura Publishing Company, Inc.

VAN DER WALT, J.J. \& VAN ROOYEN, J.M. 1977. Use of technetium-99 $\mathrm{m}$ to determine haemodynamic changes during the development of ventricular failure with gousiekte. South African Medical Journal, 52:375.

VAN DER WALT, J.J., VAN ROOYEN, J.M., CILLIERS, G.D., VAN RYSSEN, C.J. \& VAN AARDE, M.N. 1981. Ratio of car- 
diopulmonary blood volume to stroke volume as an index of cardiac function in animals and in man. Cardiovascular Research, 15:580-587

VAN ROOYEN, J.M., VAN DER WALT, J.J., JOUBERT, H. \& LÖTTER, A.P. 1984. Die beheer van haemodinamiese veranderinge tydens gousiekte. Proceedings Pharmacology and Physiology Congress, Potchefstroom, South Africa: 207208.

WEEKES, J., WHEELER, C.H., YAN, J., WEIL, J., ESCHENHAGEN, T., SCHOLTYSIK, G. \& DUNN, M.J. 1999. Bovine dilated cardiomyopathy: Proteomic analysis of an animal model of human dilated cardiomyopathy. Electrophoresis, 20:898-906.

WEISS, H.B., ELLIS, K., SCIACCA, R.R., JOHNSON, L.L., SCHMIDT, D.H. \& CANNON, P.J. 1976. Myocardial blood flow in congestive and hypertrophic cardiomyopathy. Circulation Research, 54:484-494.

WEISS, H.R., NEUBAUER, J.A., LIPP, J.A. \& SINHA, A.K. 1978. Quantitative determination of regional oxygen consumption in the dog heart. Circulation Research, 42:394-401. 